\title{
A Non-Hypersensitive Resistance in Pepper to the Bacterial Spot Pathogen Is Associated with Two Recessive Genes
}

\author{
J. B. Jones, G. V. Minsavage, P. D. Roberts, R. R. Johnson, C. S. Kousik, S. Subramanian, and R. E. Stall
}

First, second, and seventh authors: Plant Pathology Department, University of Florida, P.O. Box 110680, Gainesville 32611; third author: Southwest Florida Research and Education Center, P.O. Box 111581, Immokalee 34142; fourth author: Sakata Seed America Inc., Lehigh Acres, FL; and fifth and sixth authors: Pepper Research Inc., Loxahatchee, FL.

Accepted for publication 21 November 2001.

\begin{abstract}
Jones, J. B., Minsavage, G. V., Roberts, P. D., Johnson, R. R., Kousik, C. S., Subramanian, S., and Stall, R. E. 2002. A non-hypersensitive resistance in pepper to the bacterial spot pathogen is associated with two recessive genes. Phytopathology 92:273-277.

The pepper genotype, ECW-12346, was developed with bacterial spot resistance derived from Pep13, PI 271322, and ECW123 (Early Calwonder containing $B s 1, B s 2$, and $B s 3$ genes). For genetic analysis of this resistance, ECW12346, ECW123, $\mathrm{F}_{1}, \mathrm{~F}_{2}$, and backcrosses were inoculated with a pepper race 6 (P6) strain. Two recessive genes were identified that determined resistance. The genes are designated $b s 5$ and bs6 for the resistance derived from PI 271322 and Pep13, respectively. In greenhouse and field studies, ECW12346 was highly resistant, whereas ECW123 had significant defoliation. In growth-room studies, electrolyte

leakage and population dynamics were determined. Following infiltration of both genotypes with $10^{8} \mathrm{CFU} / \mathrm{ml}$ of a $\mathrm{P} 6$ strain, there was no rapid increase in electrolyte leakage within $72 \mathrm{~h}$, whereas a rapid increase in electrolyte leakage occurred within $24 \mathrm{~h}$ when a similar concentration of a P3 strain (containing the avrBs2 gene) was infiltrated into the intercellular spaces of the leaf. When $10^{5} \mathrm{CFU} / \mathrm{ml}$ of a P6 strain was infiltrated into leaves, complete tissue collapse was evident in ECW123 10 days later as determined by visual assessment and electrolyte leakage data, but no confluent necrosis was detected in ECW12346. Internal populations were at least two logarithmic units higher in ECW123 than in ECW12346. Therefore, ECW12346 inhibits population build-up without inducing the typical hypersensitive reaction characterized by an increase in electrolyte leakage.
\end{abstract}

Bacterial spot disease of pepper is a serious problem in many pepper production areas, especially during periods of high temperatures and high moisture (24). It is primarily incited by two Xanthomonas spp., $X$. vesicatoria and $X$. axonopodis pv. vesicatoria, in which Vauterin et al. (25) had placed the B and A group strains (2), respectively. However, as a result of DNA hybridization studies (10) the A group of strains was determined to have less than $70 \%$ homology with the type strain of $X$. axonopodis, which indicates that they should not be considered members of the same species. Thus, we will refer to the A group of strains by the previously accepted name $X$. campestris pv. vesicatoria (Xcv) until they are moved to an appropriate species. Although control strategies are implemented in which bactericides such as copper compounds or streptomycin are used, bacterial strains often are tolerant or resistant to them (2).

The major control strategy dealing with plant resistance has been to identify resistance genes associated with a hypersensitive response $(4,11-13,23)$ and introgress them into commercial genotypes by conventional or molecular techniques. Currently, three resistance genes (i.e., $B s 1, B s 2$, and $B s 3$ ) have been deployed in commercial pepper varieties. These resistance genes interact with the corresponding bacterial avirulence genes and result in an incompatible or hypersensitive reaction (18). Most strains identified in the 1990s contained one or more avirulence genes $(2,20)$, although race 6 strains were identified that contained none of the avirulence genes (21). Two of the avirulence genes ( $a v r B s 1$ and $a v r B s 3)$ are plasmid-borne $(12,17)$ and can be lost or mutations may occur (7), rendering the genes inactive. The appearance of

Corresponding author: J. B. Jones; E-mail address: Jbjones@ufl.edu

Publication no. P-2002-0117-01R

(C) 2002 The American Phytopathological Society pepper race 6 strains in commercial fields has reduced the usefulness of hypersensitive-associated resistance $(8,19)$.

A second strategy using plant resistance for controlling bacterial spot is to identify non-hypersensitive resistance and use this in combination with the hypersensitive-associated resistance genes. Genotypes with moderate resistance have been identified. McCarter (17) and Lane et al. (15) identified pepper genotypes, designated as $\mathrm{C} 44$ series, which were derived from crosses made between PI 163192 and PI 264281 that had high levels of resistance to bacterial spot. The resistance in this series was not associated with a known resistance gene that interacted with any of the known avirulence genes. S. M. McCarter identified one genotype, Pep13, derived from the $\mathrm{C} 44$ series, which had a high level of resistance to bacterial spot (S. M. McCarter, personal communication). The resistance associated with a second genotype identified in PI 271322 was backcrossed with Early Calwonder (ECW) several times to derive the line designated ECW44 (R. E. Stall, unpublished data). Resistant line ECW44 was then crossed with ECW13, a near-isogenic line of ECW, which contains the $B s 1$ and $B s 3$ genes, and backcrossed three times into ECW44 so that the resistance in ECW44 and the Bsl and Bs3 genes were maintained. The genotype was designated ECW134 LF-1. After each backcross, resistant $F_{2}$ plants were used in the next backcross to the recurrent parent.

The resistances in Pep13 and ECW134 LF-1 were combined by making crosses between Pep13 and ECW134 LF-1. $\mathrm{F}_{2}$ plants were screened for resistance by inoculating with a pepper race 6 strain, which contains none of the known avirulence genes. Plants with a high level of resistance were selected and backcrossed to ECW134 LF-1, and $F_{2}$ populations were screened. Only plants that had a high level of resistance to P6 and contained the Bsl and $B s 3$ genes were selected. This strategy was repeated three times to create ECW1346. ECW1346 was crossed with 9509-27-3 (Pepper Research, Inc., Loxahatchee, FL), a large-fruited line that contains 
$B s 1$ and Bs2. Highly resistant plants in an $\mathrm{F}_{2}$ population containing the $B s 1, B s 2$, and $B s 3$ genes and resistance to the race 6 strain were selected and backcrossed seven times into ECW134 to create ECW12346.

The objectives of this study were to (i) determine the level of field resistance associated with ECW12346 in comparison to known resistant and susceptible genotypes; (ii) determine the inheritance associated with ECW12346 that interacted specifically with pepper race 6; and (iii) characterize the type of resistance reaction by assessing the effect of genotype on population dynamics and confluent necrosis of $\mathrm{Xcv}$ when infiltrated into the leaf mesophyll.

\section{MATERIALS AND METHODS}

Bacterial strains and inoculum production. The bacterial strains used in this study were pepper race 3 strain 88-5 from Florida, pepper race 6 (P6) strains XV157 from S. Miller (OARDC, Ohio State University, Wooster) and Xcv259 from D. Ritchie (North Carolina State University, Raleigh), and pepper race 10 strain $\mathrm{Xcv} 376$ from $\mathrm{D}$. Ritchie. The strains were grown overnight in nutrient broth (BBL, Cockeysville, MD) at $28^{\circ} \mathrm{C}$, except where otherwise indicated. The bacteria were pelleted by centrifugation and resuspended in sterile tap water. The suspension was standardized to approximately $10^{8} \mathrm{CFU} / \mathrm{ml}$ by adjusting the turbidity to $A_{600}=0.3$. The cell suspension was then adjusted to the appropriate concentration by diluting in sterile tap water.

Greenhouse experiments. ECW12346 along with five other pepper genotypes were evaluated in the greenhouse at Boynton Beach for their response to P6 and P10 strains. These experiments were conducted to further confirm the results obtained in the field. PR93-2-1 and Boynton Bell are commercial bell pepper hybrids and the remaining (ECW12346, ECW123, PEP13, and Dempsey) are inbred lines. Plants were grown in 60-cell plastic trays for approximately 10 weeks in the greenhouse at temperatures ranging from 25 to $30^{\circ} \mathrm{C}$ and were transplanted into $15-\mathrm{cm}$ pots filled with Fafard Mix 4 (Fafard, Inc., Agawam, MA). The pots were fertilized once with Osmocote 14-14-14. The experimental design was a randomized complete block with six single plant replications per race per genotype. The bacterial strains, Xcv259 (P6) and Xcv376 (P10), were grown on lima bean agar (Difco Laboratories, Detroit). Inoculum for each bacterial strain was prepared separately in sterile water to a uniform concentration of $10^{5} \mathrm{CFU} / \mathrm{ml}$. Silwet L-77 (Loveland Industries, Inc., Greeley, CO) was added to the inoculum suspension at $0.04 \%$ (vol $/ \mathrm{vol}$ ) prior to inoculation. Each plant was inoculated by submersing in the inoculum suspension for $15 \mathrm{~s}$. Care was taken to reduce the risk of contamination between the two races by inoculating with only one race at a time. Foliar disease ratings were taken on all plants using

TABLE 1. Mean area under disease progress curve (AUDPC) values for pepper genotypes as affected by bacterial spot races 6 and 10 in greenhouse experiments at Boynton Beach during 1999 and 2000y

\begin{tabular}{lcccccccc}
\hline & \multicolumn{3}{c}{ Mean AUDPC $(1999)^{\mathrm{z}}$} & & \multicolumn{3}{c}{ Mean AUDPC $(2000)^{\mathrm{z}}$} \\
\cline { 2 - 3 } \cline { 7 - 8 } Genotype & Race 6 & Race 10 & Overall & & Race 6 & Race 10 & Overall \\
\hline PR93-2-1 & $215 \mathrm{a}$ & $189 \mathrm{ab}$ & $202 \mathrm{a}$ & & $110 \mathrm{a}$ & $132 \mathrm{a}$ & $121 \mathrm{a}$ \\
Boynton Bell & $190 \mathrm{bc}$ & $203 \mathrm{a}$ & $197 \mathrm{a}$ & & $113 \mathrm{a}$ & $121 \mathrm{ab}$ & $117 \mathrm{a}$ \\
ECW123 & $168 \mathrm{~cd}$ & $170 \mathrm{~b}$ & $169 \mathrm{~b}$ & & $103 \mathrm{a}$ & $125 \mathrm{a}$ & $114 \mathrm{ab}$ \\
Pep13 & $156 \mathrm{~d}$ & $130 \mathrm{c}$ & $145 \mathrm{c}$ & & $98 \mathrm{a}$ & $107 \mathrm{~b}$ & $103 \mathrm{~b}$ \\
Dempsey & $98 \mathrm{e}$ & $135 \mathrm{c}$ & $116 \mathrm{~d}$ & & $55 \mathrm{~b}$ & $80 \mathrm{c}$ & $67 \mathrm{c}$ \\
ECW12346 & $58 \mathrm{f}$ & $86 \mathrm{~d}$ & $72 \mathrm{e}$ & & $37 \mathrm{c}$ & $33 \mathrm{~d}$ & $35 \mathrm{~d}$ \\
\hline
\end{tabular}

y Means within a column followed by the same letter do not differ significantly based on Duncan's multiple range test $(P=0.05)$.

${ }^{z}$ Mean AUDPC is based on six foliar disease ratings in 1999 and five in 2000 taken on a 0 to 9 scale (14) in which $0=$ no diseased leaves and $9=$ plants completely defoliated or dead. Overall AUDPC is the mean of AUDPC for races 6 and 10 a visual disease severity scale of 0 to 9 , with $0=$ no lesions observed, $1=$ trace but less than $1 \%$ leaf area diseased, $2=1$ to $10 \%$ leaf area diseased, $3=11$ to $20 \%$ leaf area diseased or defoliated, $4=21$ to $35 \%$ leaf area diseased or defoliated, $5=36$ to $50 \%$ leaf area diseased or defoliated, $6=51$ to $65 \%$ leaf area diseased or defoliated, $7=66$ to $80 \%$ leaf area diseased or defoliated, $8=81$ to $99 \%$ leaf area diseased or defoliated, and $9=$ complete defoliation (14). These data were used to calculate areas under the disease progress curves (AUDPC) as described by Campbell and Madden (3). The experiments were conducted in 1999 and 2000.

Field experiments. In experiment 1 (southwest Florida), transplants were produced by sowing seeds on 21 July in 242 cell standard-sized flats. Plants were transplanted to the field on $18 \mathrm{Sep}-$ tember. Plots contained 20 plants spaced at $25 \mathrm{~cm}$ within a row and planted in a double row into four $75 \mathrm{~cm} \times 150 \mathrm{~m}$ length raised beds covered with plastic mulch following fumigation (16). Drip irrigation and fertilization were applied according to standard pepper production (16). Buffer rows consisted of the susceptible genotype 'Jupiter Sterling' planted on either side of test plots and at the end of rows. Plants were inoculated with P6 strain Xv157 in the field with a hand-pumped backpack sprayer on 1, 4, 6, 8, and 21 October by applying $657 \mathrm{ml}$ of inoculum per $30 \mathrm{~m}$ to the undersides of plants on each side of the double row. Plants were assessed for disease severity at 2-week intervals on a scale of 1 to 9, with 1 indicating no disease and a rating of 9 indicating dead. Disease ratings for each plot were used to calculate AUDPC. Pepper fruit were harvested once on 2 December and graded according to U.S. standards for grades of pepper in the categories of U.S. Fancy, U.S.1, and nonmarketable due to either small or misshapen size. Yields were normalized for missing plants. Yield data and AUDPC were subjected to analysis of variance (ANOVA), and the means were tested for significance using Duncan's multiple range test provided by SAS for Windows (Cary, NC).

In experiment 2 (Gainesville), pepper seedlings were transplanted to Speedling flats, grown to transplant size, and inoculated with the P6 strain by infiltrating a leaflet of each plant with a bacterial suspension adjusted to approximately $10^{7} \mathrm{CFU} / \mathrm{ml}$. The transplants were set in the field on 6 August in a randomized complete block design consisting of 10 plants per plot and four replications. Plants were spaced $30 \mathrm{~cm}$ apart in each plot and $90 \mathrm{~cm}$ apart between plots. The plots were assessed for disease severity using the Horsfall-Barrett system (9).

Inheritance of resistance. ECW123 $\left(\mathrm{P}_{\mathrm{s}}\right)$ and ECW12346 $\left(\mathrm{P}_{\mathrm{r}}\right)$ were used as parents. The former line was selected because it contained the same $\mathrm{R}$ genes as the resistant parent, which would not be a confounding factor. Seedlings representing the parents, $F_{1}, F_{2}$, $\mathrm{BcP}_{\mathrm{s}}$, and $\mathrm{BcP}_{\mathrm{r}}$ were transplanted into a soilless mix in $10-\mathrm{cm}$ pots and grown under greenhouse conditions for approximately 3 weeks. The first true leaves were infiltrated with approximately $10^{5} \mathrm{CFU} / \mathrm{ml}$ of P6 strain Xv157. The inoculated plants remained

TABLE 2. Area under disease progress curve (AUDPC) and disease severity values for pepper genotypes as affected by bacterial spot in the fall $1999^{\mathrm{z}}$

\begin{tabular}{lccc}
\hline & Experiment 1 & & Experiment 2 \\
\cline { 2 - 2 } Genotype & AUDPC & & Disease severity \\
\hline ECW123 & $129.4 \mathrm{a}$ & & $4.8 \mathrm{a}$ \\
Jupiter & $124.9 \mathrm{a}$ & & - \\
Boynton Bell & $103.1 \mathrm{~b}$ & & $3.8 \mathrm{~b}$ \\
Pep13 & $76.9 \mathrm{c}$ & & $2.0 \mathrm{c}$ \\
Dempsey & $57.6 \mathrm{~cd}$ & & $3.0 \mathrm{bc}$ \\
ECW12346 & $51.1 \mathrm{~d}$ & & $2.0 \mathrm{c}$ \\
\hline
\end{tabular}

${ }^{\mathrm{z}}$ Experiment 1 and experiment 2 were conducted in southwest Florida and Gainesville, respectively. Values represent percent defoliation based on Horsfall-Barrett Scale (9). Disease severity was generated from four disease ratings. Values in each column followed by the same letter are not significantly different according to Duncan's multiple range test $(P=0.05)$. Jupiter was not included in the Gainesville experiment. 
in the greenhouse for the remainder of the experiment and were rated for disease 3 weeks after inoculation. The rating scale for estimating disease severity used was: 1 = no disease symptoms; $2=$ slight to moderate yellowing and slight necrosis; $3=$ extensive yellowing and moderate necrosis; and $4=$ complete necrosis.

Each of the $96 \mathrm{~F}_{2}$ plants was allowed to self-pollinate and $\mathrm{F}_{3}$ seeds were obtained from each of them. Twenty-four $\mathrm{F}_{3}$ seedlings from each intermediate or resistant $F_{2}$ plant were scored for disease reactions, whereas only $12 \mathrm{~F}_{3}$ plants from each susceptible $\mathrm{F}_{2}$ plant were scored. The plants were grown and inoculated as previously described.

Electrolyte leakage. ECW123 and ECW12346 seedlings were transplanted to soilless mix in $10-\mathrm{cm}$ pots and grown for approximately 4 weeks in the greenhouse. Mature leaves were infiltrated with $10^{5}$ or $10^{8} \mathrm{CFU} / \mathrm{ml}$ of P3 strain $88-5$ or P6 strain Xv157. Plants were incubated in a growth room at $28^{\circ} \mathrm{C}$ on a 12 -h light cycle. For plants infiltrated at $10^{8} \mathrm{CFU} / \mathrm{ml}$, three leaves were collected for each treatment every $12 \mathrm{~h}$ beginning at $0 \mathrm{~h}$ and assayed independently for electrolyte leakage as described by Cook and Stall (6). For plants inoculated with $10^{5} \mathrm{CFU} / \mathrm{ml}$, three leaves for each treatment were assayed for electrolyte leakage at 0, 2, 4, 6, 8, and 10 days after infiltration. For statistical analysis, the area under the electrolyte leakage curve (AUELC) was determined using the program developed for AUDPC. The experiment was set up as a completely randomized block design and the AUELCs were analyzed using PROC ANOVA provided by SAS for Windows (Cary, NC).

Internal bacterial populations. ECW123 and ECW12346 seedlings were transplanted to soilless mix in $10-\mathrm{cm}$ pots and grown for approximately 4 weeks. Mature leaves were infiltrated with $10^{5} \mathrm{CFU} / \mathrm{ml}$ of P3 strain $88-5$ or P6 strain Xv157. Plants were incubated in a growth room at $28^{\circ} \mathrm{C}$ with a 12 -h light period. Three leaves were collected for each treatment at $0,2,4,6,8$, and 10 days. Bacterial populations were determined by removing two $0.5-\mathrm{cm}^{2}$ leaf disks from the infiltrated area, grinding the disks in $1 \mathrm{ml}$ of sterile distilled water, and plating the appropriate dilutions on nutrient agar. For statistical analysis, the area under the population curve was determined using the program developed for AUDPC. The experiment was analyzed as described previously.

\section{RESULTS}

Greenhouse experiments. Results from the two greenhouse experiments conducted at Boynton Beach were similar both years (Table 1). Bacterial spot disease severity on the susceptible checks ECW123, Boynton Bell, and PR93-2-1 was high by 3 weeks after inoculation. ECW12346 had significantly less disease compared

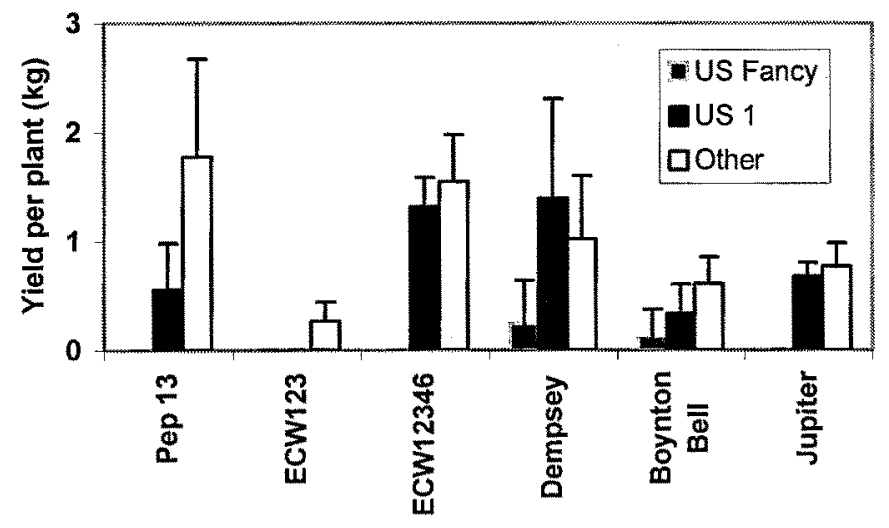

Fig. 1. Fruit yield of selected pepper genotypes in a fall 1999 field trial following inoculation with the bacterial spot pathogen. Fruit were graded according to U.S. standards for grades of pepper in the categories of U.S. Fancy, U.S.1, and nonmarketable (other) due to either small or misshapen size. with the susceptible checks and Dempsey. Dempsey had significantly lower disease than ECW123.

Field experiments. In experiment 1, disease was most severe on ECW123 and Jupiter (Table 2). Disease severity was slightly but significantly lower on Boynton Bell. Dempsey and ECW12346 consistently had the lowest disease severity, whereas Pep13 had slightly higher ratings. Analysis of the AUDPC values revealed that Jupiter and ECW123 had significantly higher AUDPC values followed by Boynton Bell and Pep13. ECW12346 and Dempsey had the lowest values, although the latter genotype was not significantly lower than Pep13. Yield was reduced most extensively in Jupiter, ECW123, and Boynton Bell (Fig. 1). Pep13, ECW12346, and Dempsey had approximately the same fruit weight per plant. In a similar field test conducted in Boynton Beach where no disease was present, Pep13 and ECW12346 had significantly lower fruit yield than Boynton Bell, whereas Dempsey was not significantly different from any of the genotypes (data not shown).

In experiment 2 , a disease severity rating was made approximately 75 days following transplanting to the field. ECW12346 and Pep13 had significantly less disease than ECW123 and Boynton Bell (Table 2).

Inheritance of resistance. Inoculation of the susceptible parent resulted in all 12 plants having complete necrosis (i.e., disease rating of 4) in the inoculated area (Table 3). All resistant parent plants (i.e., ECW12346) had no apparent disease (i.e., disease rating of 1). All but one of the $24 \mathrm{~F}_{1}$ plants were rated as $4 \mathrm{~s}$, while the remaining $F_{1}$ plant was rated a 3 . The $F_{2}$ population segregated into four disease reaction types. Of the $96 \mathrm{~F}_{2}$ plants tested, seven produced a resistant reaction of 1,17 plants produced slight yellowing and minimal necrosis and were rated 2, 14 plants had significant necrosis and yellowing in the inoculated area and were rated 3 , and 58 produced the susceptible disease reaction of 4 . As a result of the four disease reactions, and the low number of resistant and intermediate reactions compared with susceptible reactions (i.e., 58), the data were analyzed to determine if they fit the segregation of two recessive genes or a 1:3:3:9 ratio. Based on chi-square analysis, the $\mathrm{F}_{2}$ data fit two recessive genes. Chi-square analysis of the $\mathrm{F}_{1}, \mathrm{BcP}_{\mathrm{r}}$, and $\mathrm{BcP}_{\mathrm{s}}$ was fully supportive of the $\mathrm{F}_{2}$ data for two recessive genes. Homozygous recessive genes at either locus resulted in an intermediate response.

As a result of screening the $F_{3}$ plants, several initial $F_{2}$ ratings were placed in the wrong category. The $\mathrm{F}_{3}$ progenies of six of the seven $F_{2}$ plants receiving a score of 1 were homozygous for a 1 rating and were thus homozygous recessive at the five and six loci, because both genes are needed for a rating of 1 ; however, progeny from the seventh plant were found to be heterozygous and contained plants that were scored as 1 and 2 . Thus, one $F_{2}$ plant was incorrectly rated as a 1 and should have been scored as a 2. One of the progenies of the $17 \mathrm{~F}_{2}$ plants receiving a rating of 2 contained only plants scored as 1 , and thus was homozygous for category 1 . The parent of that progeny was originally rated as a 2 but should have been scored as 1 . Two other progenies in this group contained plants scored as 3 , and the parents were moved to

TABLE 3. Genetic analysis of various pepper genotypes based on disease reactions following leaf infiltration with Xanthomonas campestris pv. vesicatoria pepper race 6

\begin{tabular}{|c|c|c|c|c|c|c|c|}
\hline \multirow[b]{2}{*}{ Genotype } & \multirow{2}{*}{$\begin{array}{l}\text { Total } \\
\text { plants }\end{array}$} & \multicolumn{4}{|c|}{ Disease rating ${ }^{\mathrm{z}}$} & \multirow{2}{*}{$\begin{array}{l}\text { Expected } \\
\text { ratio }\end{array}$} & \multirow[b]{2}{*}{$\chi^{2}(P)$} \\
\hline & & 1 & 2 & 3 & 4 & & \\
\hline $\operatorname{ECW} 123\left(\mathrm{P}_{\mathrm{s}}\right)$ & 12 & 0 & 0 & 0 & 12 & $0: 0: 0: 1$ & . \\
\hline ECW12346 $\left(\mathrm{P}_{\mathrm{r}}\right)$ & 12 & 12 & 0 & 0 & 0 & 1:0:0:0 & $\ldots$ \\
\hline $\mathrm{F}_{1}$ & 24 & 0 & 0 & 1 & 23 & $0: 0: 0: 1$ & $\ldots$ \\
\hline $\mathrm{F}_{2}$ & 96 & 7 & 17 & 14 & 58 & $1: 3: 3: 9$ & $1.414(>0.70)$ \\
\hline $\mathrm{BcP}_{\mathrm{s}}$ & 48 & 0 & 0 & 2 & 46 & $0: 0: 0: 1$ & $0.040(>0.999)$ \\
\hline $\mathrm{BcP}_{\mathrm{r}}$ & 48 & 14 & 9 & 13 & 12 & $1: 1: 1: 1$ & $0.500(>0.70)$ \\
\hline
\end{tabular}

z 1 = no disease symptoms; 2 = slight to moderate yellowing; 3 = yellowing and some necrosis; and $4=$ complete necrosis. 
the category 3 rating. Of the remaining 14 progenies, three were homozygous recessive at the 2 locus and homozygous dominant at the 3 locus. Eleven progenies were homozygous recessive at the 2 locus, but heterozygous at the 3 locus. Heterozygosity at the 3 locus resulted in plants with a score of 1 in the progeny. Of the progenies of the 14 plants rated as 3 , two contained plants rated as 2 and the parents of these were again improperly categorized. Of the remaining 12 progenies, five were homozygous recessive at the 3 category and homozygous dominant at the 2 locus. Seven progenies contained plants that were heterozygous dominant at the 2 locus. The progenies of the 58 plants scored as 4 (susceptible) each contained susceptible plants. Thus, the susceptible plants in the $\mathrm{F}_{2}$ population were accurately scored.

Of the 96 plants in the $F_{2}$ generation, only six were mistakenly categorized and then by only one level of resistance. When these six plants were placed in their correct categories, the ratios of plants in each category did not change. Thus, the scoring of each plant in the inheritance test was supported by progeny testing.

Electrolyte leakage. A rapid increase in electrolyte leakage occurred within $12 \mathrm{~h}$ in leaves of ECW123 and ECW12346 infiltrated with $10^{8} \mathrm{CFU} / \mathrm{ml}$ of the P3 strain (Fig. 2A). Electrolyte leakage remained low in ECW123 and ECW12346 leaves up to $60 \mathrm{~h}$ after infiltration with the P6 strain. In leaves of ECW123 and ECW12346 infiltrated with $10^{5} \mathrm{CFU} / \mathrm{ml}$ of the $\mathrm{P} 3$ strain, no rapid increase in electrolyte leakage occurred within 10 days (Fig. 2B). Similar results were observed in leaves of ECW12346 infiltrated with a P6 strain. However, there was an increase in electrolyte leakage in the compatible interaction of leaves of ECW123 in-
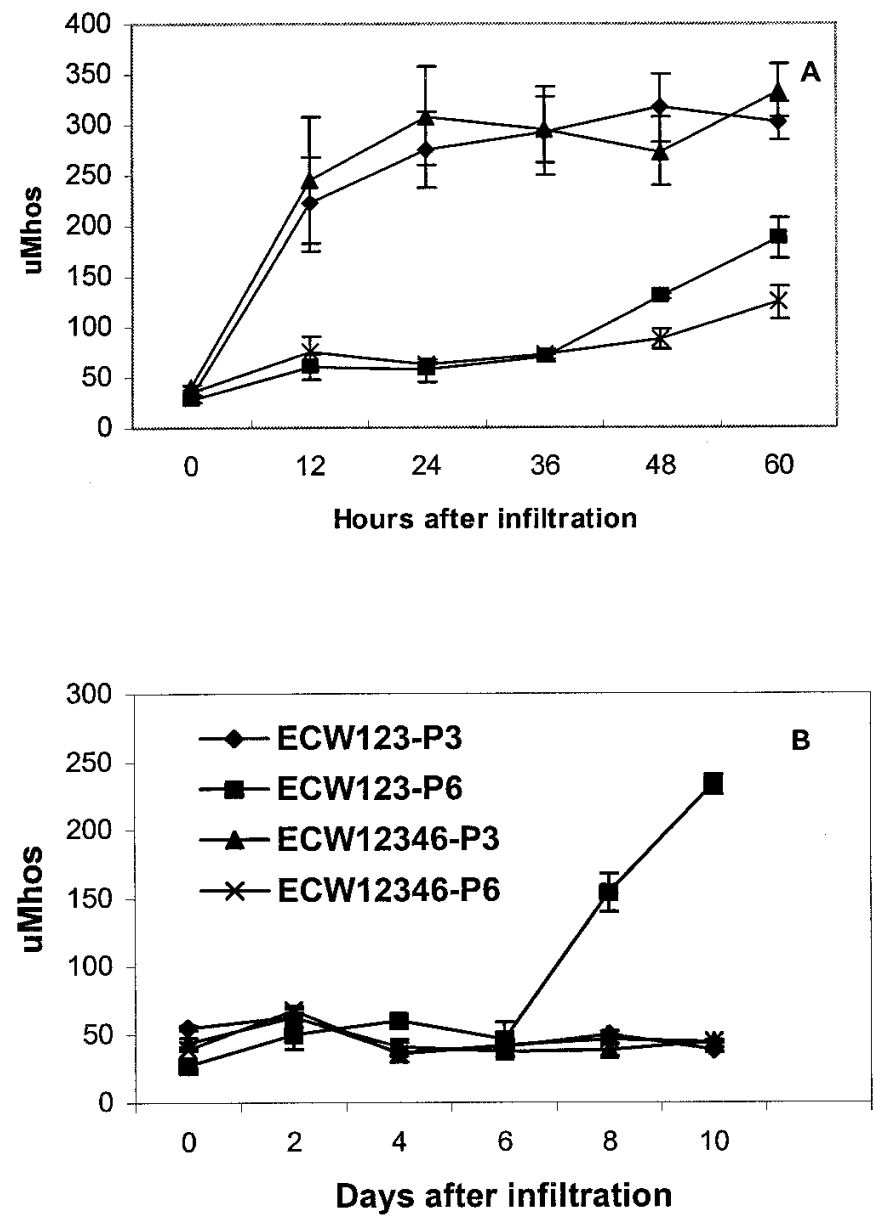

Fig. 2. The effect of infiltration with $\mathbf{A}, 10^{8} \mathrm{CFU} / \mathrm{ml}$ or $\mathbf{B}, 10^{5} \mathrm{CFU} / \mathrm{ml}$ of a P3 or P6 strain of Xanthomonas campestris pv. vesicatoria into leaves of ECW123 or ECW12346 on electrolyte leakage, respectively. Bars for each data point represent the standard error. filtrated with the P6 strain beginning approximately 6 days after being infiltrated.

Internal bacterial populations. Bacterial populations increased rapidly in leaves of ECW123 infiltrated with the P6 strain (Fig. 3). Intermediate bacterial populations were observed in the leaves of ECW12346 infiltrated with P6 and in the incompatible interaction (i.e., P3 infiltrated into ECW123). Internal populations basically remained unchanged in the incompatible interaction (i.e., P3 infiltrated into leaves of ECW12346).

\section{DISCUSSION}

In recent years, P6 strains have become prevalent in pepper fields where varieties that contain the resistance genes $B s 1, B s 2$, and $B s 3$ to the bacterial spot pathogen are grown $(19,21)$. In the present study, genotype ECW12346 demonstrated a high level of greenhouse and field resistance to race P6. It was also shown that $\mathrm{P} 6$, which induces a compatible interaction in pepper genotypes containing the three pepper resistance genes ( $B s 1, B s 2$, and $B s 3)$, caused significant defoliation in two genotypes containing the three resistance genes. In the two field tests, defoliation in the variety containing the three resistance genes was similar or close to that observed in a variety that contained no resistance genes. This is in agreement with the work of Kousik and Ritchie (14) in which they demonstrated that $X$. campestris pv. vesicatoria strains lacking the $a v r B s 1, a v r B s 2$, and $a v r B s 3$ cause significant defoliation in pepper genotypes containing the three resistance genes.

The resistance in ECW12346 to P6 appears to be associated with the interaction of $X$. campestris pv. vesicatoria strains with resistance genes that are not involved in hypersensitivity. This was determined by quantifying electrolyte leakage. No rapid increase occurred in ECW12346 following infiltration with $10^{8} \mathrm{CFU} / \mathrm{ml}$ of a P6 strain, whereas a rapid increase in electrolyte leakage occurred in ECW123 or ECW12346 when leaves were infiltrated with a P3 strain. In the former case, there appeared to be no interaction between an avirulence gene and corresponding resistance gene, whereas in the latter two cases, the rapid increase was typical of such an interaction. When plants were infiltrated with the lower $\left(10^{5} \mathrm{CFU} / \mathrm{ml}\right)$ concentration, electrolyte leakage increased only in the compatible interaction between P6 and ECW123. None of the other treatments, including the P6-ECW12346 interaction, resulted in an increase in electrolyte leakage. The fact that electrolyte leakage did not increase significantly in P6-ECW12346infiltrated leaves throughout the course of the experiment strongly

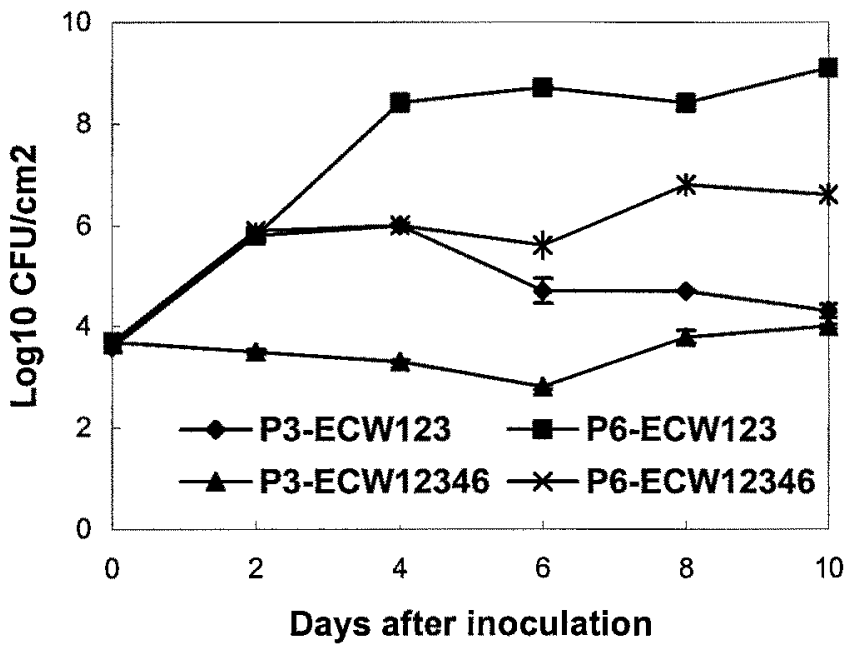

Fig. 3. The effect of infiltration with $10^{5} \mathrm{CFU} / \mathrm{ml}$ of a $\mathrm{P} 3$ or $\mathrm{P} 6$ strain of Xanthomonas campestris pv. vesicatoria into leaves of ECW123 or ECW12346 on internal bacterial populations. Bars for each data point represent the standard error. 
suggests that this genotype is suppressing disease development as a result of a nonhypersensitive type of resistance mechanism.

The population results corroborated those derived from electrolyte leakage at $10^{5} \mathrm{CFU} / \mathrm{ml}$ in that the only significant increase in internal populations occurred in the compatible interaction (i.e., P6-ECW123). The incompatible interactions (i.e., P3-ECW123 or P3-ECW12346) and the P6-ECW12346 interaction resulted in at least a two log unit reduction in internal populations. In the case of the P6-ECW12346 interaction, the non-hypersensitive-associated resistance apparently was responsible for suppressing internal populations. The fact that there was no rapid increase in electrolyte leakage associated with infiltration of the P6 strain into ECW12346, but a significant reduction in internal populations, suggests that a type of resistance apart from the typical hypersensitive-associated resistance (6) is responsible.

In one of the experiments, there was a response involving the P3 strain, the $B s 2$ gene, and the general resistance associated with ECW12346. Although populations usually increase at least two $\log$ units in leaves during incompatible interactions, there was no such increase in the bacterial populations over the 10-day sampling period. Furthermore, populations of the P3 strain in ECW12346 were close to two log units lower than in the P3-ECW123 interaction.

The resistance in ECW12346, which interacted with the P6 strain, was determined to be associated with two recessive genes. As a result of the presence of four resistance genes in pepper $(B s 1$, $B s 2, B s 3$, and $B s 4$ [22]), the two resistance genes associated with the category 3 and 2 reactions, as identified in this study, are designated $b s 5$ and $b s 6$, respectively. In most instances, the disease resistance attributed to each of theses genes can easily be distinguished based on the disease reactions. The former was derived from PI 271322, whereas the latter was associated with the C44 series, as described by McCarter (17) and Lane et al. (15) and derived from PI 264281 and PI 163192. This type of resistance is very different from previously published reports of resistance in pepper and tomato. Previously published reports of resistance genes that have been characterized in pepper include the $B s 1, B s 2$, and $B s 3$ genes, which are dominant $(4-6,13)$, and in tomato include $X v 4$ and $R x v$, which are dominant (1) and incompletely dominant (23), respectively. Selecting for the resistance associated with the non-hypersensitive resistance in ECW12346 is easily attained by infiltrating a low concentration $\left(\approx 10^{5} \mathrm{CFU} / \mathrm{ml}\right)$ of a P6 strain into the leaf of an $\mathrm{F}_{2}$ population and determining disease response. Plants that react similarly to ECW12346 have a high level of resistance. Although we have presented much information concerning the combined effects of the $b s 5$ and $b s 6$ genes, further work is necessary to determine the individual roles of the two genes in terms of affecting bacterial populations and electrolyte leakage.

\section{ACKNOWLEDGMENTS}

Florida Agriculture Experiment Station Journal Series R-08396.

\section{LITERATURE CITED}

1. Astua-Monge, G., Minsavage, G. V., Stall, R. E., Vallejos, C. E., Davis, M. J., and Jones, J. B. 2001. Xv4-avrXv4: A new gene-for-gene interaction identified between Xanthomonas campestris pv. vesicatoria race T3 and the wild tomato relative Lycopersicon pennellii. Mol. Plant Microbe-Interact. 13:1346-1355.

2. Bouzar, H., Jones, J. B., Stall, R. E., Hodge, N. C., Minsavage, G. V.,
Benedict, A. A., and Alvarez, A. M. 1994. Physiological, chemical, serological, and pathogenic analyses of a worldwide collection of Xanthomonas campestris pv. vesicatoria strains. Phytopathology 84:663-671.

3. Campbell, C. L., and Madden, L. V. 1990. Introduction to Plant Disease Epidemiology. John Wiley \& Sons, New York.

4. Cook, A. A. 1973. Characterization of hypersensitivity in Capsicum annuum induced by the tomato strain of Xanthomonas vesicatoria. Phytopathology 63:915-918.

5. Cook, A. A., and Guevara, Y. G. 1984. Hypersensitivity in Capsicum chacoense to race 1 of the bacterial spot pathogen of pepper. Plant Dis. 68:329-330.

6. Cook, A. A., and Stall, R. E. 1963. Inheritance of resistance in pepper to bacterial spot. Phytopathology 53:1060-1062.

7. Dahlbeck, D., and Stall, R. E. 1979. Mutations for change of race in cultures of Xanthomonas vesicatoria. Phytopathology 69:634-636.

8. Gassmann, W., Dahlbeck, D., Cjesnokova, O., Minsavage, G. V., Jones, J. B., and Staskawicz, B. J. 2000. Molecular evolution of virulence in natural field strains of Xanthomonas campestris pv. vesicatoria. J. Bacteriol. 182:7053-7059.

9. Horsfall, J. G., and Barratt, R. W. 1945. An improved grading system for measuring plant diseases. Phytopathology 35:655.

10. Jones, J. B., Bouzar, H., Stall, R. E., Almira, E. C., Roberts, P. D., Bowen, B. W., Sudberry, J., Strickler, P. M., and Chun, J. 2000. Systematic analysis of xanthomonads (Xanthomonas spp.) associated with pepper and tomato lesions. Int. J. Syst. Bacteriol. 50:1211-1219.

11. Jones, J. B., and Scott, J. W. 1986. Hypersensitive response in tomato to Xanthomonas campestris pv. vesicatoria. Plant Dis. 70:337-339.

12. Jones, J. B., Stall, R. E., and Bouzar, H. 1998. Diversity among xanthomonads pathogenic on pepper and tomato. Annu. Rev. Phytopathol. 36:41-58.

13. Kim, B. S., and Hartmann, R. W. 1985. Inheritance of a gene (Bs3) conferring hypersensitive resistance to Xanthomonas campestris pv. vesicatoria in pepper (Capsicum annuum). Plant Dis. 69:233-235.

14. Kousik, C. S., and Ritchie, D. F. 1996. Disease potential of pepper bacterial spot pathogen races that overcome the $B s 2$ gene for resistance. Phytopathology 86:1336-1343.

15. Lane, R. P., McCarter, S. M., Kuhn, C. W., and Deom, C. M. 1997. Dempsey, a virus- and bacterial spot-resistant bell pepper. HortScience 32:333-334.

16. Maynard, D. N., and Olson, S. M. 2000. Vegetable production guide for Florida. Fla. Coop. Ext. Serv. Circ. SP-170.

17. McCarter, S. M. 1992. Effects of bactericide treatments on bacterial spot severity and yield of different pepper genotypes and on populations of certain insects. Plant Dis. 76:1042-1045.

18. Minsavage, G. V., Dahlbeck, D., Whalen, M. C., Kearney, B., Bonas, U., Staskawicz, B., and Stall, R. E. 1990. Gene-for-gene relationships specifying disease resistance in Xanthomonas campestris pv. vesicatoriapepper interactions. Mol. Plant-Microbe Interact. 3:41-47.

19. Pernezny, K., Collins, J., Stall, R. E., Shuler, K., and Datnoff, L. E. 1999. A serious outbreak of race 6 of Xanthomonas campestris pv. vesicatoria on pepper in southern Florida. Plant Dis. 83:79.

20. Pohronezny, K., Stall, R. E., Canteros, B. I., Kegley, M., Datnoff, L. E., and Subramanya, R. 1992. Sudden shift in the prevalent race of Xanthomonas campestris pv. vesicatoria in pepper fields in southern Florida. Plant Dis. 76:118-120.

21. Sahin, F., and Miller, S. A. 1996. Characterization of Ohio strains of Xanthomonas campestris pv. vesicatoria, causal agent of bacterial spot of pepper. Plant Dis. 80:773-778.

22. Sahin, F., and Miller, S. A. 1997. A source of resistance in Capsicum spp. accessions to pepper race 6 of Xanthomonas campestris pv. vesicatoria. (Abstr.) Phytopathology 87:S84.

23. Scott, J. W., and Jones, J. B. 1989. Inheritance of resistance to foliar bacterial spot of tomato incited by Xanthomonas campestris pv. vesicatoria. J. Am. Soc. Hortic. Sci. 114:111-114.

24. Stall, R. E. 1995. Xanthomonas campestris pv. vesicatoria. Pages 167184 in: Pathogenesis and Host Specificity in Plant Diseases: Histological, Biochemical, Genetic and Molecular Bases. Vol. 1, Prokaryotes. U. S. Singh, R. P. Singh, and K. Kohmoto, eds. Pergamon, Elsevier Science, Tarrytown, NY.

25. Vauterin, L., Hoste, B., Kersters, K., and Swings, J. 1995. Reclassification of Xanthomonas. Int. J. Syst. Bacteriol. 45:472-489. 